\title{
A Holistic Design Perspective on Entrepreneurship Education
}

\author{
Kirsten Bonde Sørensen ${ }^{1, *}$, Helle Munkholm Davidsen ${ }^{2}$ \\ ${ }^{1}$ Department for Learning and Philosophy, Aalborg University, Denmark \\ ${ }^{2}$ Research and Development, Continuing Education, VIA University College, Denmark
}

Copyright $\bigcirc 2017$ by authors, all rights reserved. Authors agree that this article remains permanently open access under the terms of the Creative Commons Attribution License 4.0 International License

\begin{abstract}
Entrepreneurship has revealed a new way of considering learning in educational institutions; but it presents a challenge to most schools. Entrepreneurial learning is asking the teachers to allow pupils to see new possibilities, take initiatives and be self-directed. However, this is difficult for teachers, since they are used to being in control of the teaching and are fixated on conventional curricula, teaching methods, use of knowledge, teaching styles, teacher-student relations, culture, habitat and assessments [1]. In entrepreneurship education, we tend to have a single focus, e.g. 'motivation', 'self-directed learning', 'learning goals' etc., but maybe we need to broaden our focus and look at the bigger picture. The main question in this paper is: how can we understand the challenge that entrepreneurial learning poses to the teacher's role and the learning culture in schools and additionally, how can we develop entrepreneurial education that meets these challenges? The paper refers to our research in a public school. Based on this research and additional literature review $[1,2,3,4,5,6,7,8,9,10,11]$ we suggest adding a design approach to entrepreneurship education. Additionally, we present a design approach that also takes the student's personal and inner focus into account.
\end{abstract}

Keywords Entrepreneurship Education, Design Thinking, Self-directed Learning, Value Clarification, Human Creative Skills, Inner Focus

\section{Introduction}

\subsection{A Paradigmatic Conflict in Entrepreneurship Education}

The challenges that entrepreneurial learning poses to both the teacher's role and to the learning culture reflect a paradigmatic conflict in entrepreneurship. As Robinson and Blenker [12] argue, there is a conflict between the philosophical, autonomous and emancipative spirit and the controlling and regulative management logic in the entrepreneurship literature. Likewise Pittaway \& Edwards [13] have identified four different forms of entrepreneurship education: "about," "for," "through" and "embedded" and points to research that shows most entrepreneurship education is undertaken through teaching "about" and includes more traditional pedagogic forms of educational practice in which students are passive receivers of knowledge. Entrepreneurship cannot be taught as a conventional academic topic [14]. Nonetheless, like in all other classes, students are not involved in activities or tasks that enable them to acquire entrepreneurial skills. Traditional (entrepreneurship) education is detached from practice and does not allow students to get a real-life experience [13]. In traditional education life stops when we learn. But learning is continual and needs to be "in sync with life" [15]. In other words, we need to have a stronger connection between practice and real life [15].

In the perspective of this paradigmatic conflict entrepreneurial education needs to be developed in a way that better meets this challenge. As we argue below there are different central themes and issues that relate to this paradigmatic conflict:

\subsection{Creativity and Imagination}

Numerous educational researchers have highlighted the central role of creativity and imagination in entrepreneurship and in education at large. Nonetheless, little explicit attention has been given to creativity and imagination in the entrepreneurship literature and entrepreneurship education literature [1].

However, creativity and imagination are central capacities not only in relation to building a business, but they are also basic skills to attune to changing environments, making changes and shaping an unknown future $[4,5,2,3,16,17,7$, 6]. In regard to creativity and imagination Greene and Langer argue that it is crucial for human beings to be conscious about themselves, their predefinitions and their 
mental steering models which enable them to see opportunities and break with the well-known $[3,16]$. For Greene learning is not about filling students' brains with knowledge but about helping them to develop the ability to create meaning. Likewise, Greene considers education to be about helping human beings to create themselves. "Identity is never fixed, we are always becoming," Greene stated [16, 17].

Although Greene's theories are several decades old they still seem utterly relevant, particularly in the perspective of recent knowledge about cognition and the possibilities of controlling and changing dominant values and thinking patterns $[16,6,62]$.

\subsection{A Broader Focus}

Apart from creativity and imagination, we also need a broader perspective in order to better understand and comply with the increasing complexity of the world. Most of the principles we use in our way of organising and leading our organisations stem from a radically different time. Our businesses and organisations - including our educational institutions - are dominated by mental models rooted in Industrial Scientific Management, which taught us to think in linear cause-and-effect patterns and break down problems into parts rather than seeing wholes and connections [18]. Instead, we need a more holistic approach and awareness and a better understanding of all our systems, i.e. systems thinking. Systems operate everywhere; the family is a system, the school, the playground, every organisation is a system etc. [7].

In this paradigmatic conflict, we consider design thinking as a parallel to systems thinking, since it offers a holistic perspective. Contrary to systems thinking is it not only analytical, but is centred around creativity and imagination, seeing and actively creating new possibilities. This paper presents design thinking used not only for objective but also for subjective issues $[11,19]$. Thus, design thinking offers a perspective that can be used for the human development that Greene, Langer, Robinson, Goleman \& Senge stand for, as well as for the more market-oriented perspective which is central in both design and particularly in entrepreneurship literature.

\subsection{Design Thinking - A New Holistic View \& Perspective}

Design is often seen as a product, but design can also represent the underlying design activity, the design process or design thinking in which both creativity and imagination are key concepts. In recent years, there has been a growing focus on design thinking within the business community. Several researchers and practitioners have introduced new notions, methods and theories: design management \& design leadership [20,21], design business modelling [22] and service design $[23,24]$.
A design approach or design thinking is also represented in Boland \& Collopy's notions 'design attitude' versus 'decision attitude' [20]. The decision attitude rests on the assumption that the difficult task in managing is selecting among alternatives, whereas a design attitude assumes that managing means to generate and create better alternatives. In this sense a design attitude or design thinking focusses on 'what might be' rather than on 'what is'. Michlewski has identified the qualities included in a design attitude. They include: empathy, a willingness to embrace ambiguity, the desire to engage and use one's senses to learn, exploring and expressing oneself, an appreciation of complexities that have qualities that go beyond their parts, and an interest in actually making things $[25,26]$.

Design thinking is often described as "... [an] open and human-centred approach to solving problems" [1]. But the application of design approach/design thinking is not limited to objective problems outside of oneself; it also includes subjective issues - regarding value clarification, changes of dominant values and, as such, changes in human development, as described by Sørensen [10, 19, 11]. Dunne \& Martin [27] emphasise that education based on the rationale of design and design thinking teaches students to focus on 'what might be'. Thus, it offers a radically different approach to the world focussing on imagination, the creation of possibilities and an unknown future, which is essential in entrepreneurship [28].

In the field of entrepreneurship, design and design thinking have only received scant attention. In this paper we will refer to a recent paper that introduces design thinking in entrepreneurship education represented in the "DesUni model" [1]. Nielsen \& Storvang's article offers an overall argumentation for why and how design thinking has relevance in entrepreneurship education. In another research paper (Sørensen \& Evers, 2015) design thinking is introduced in entrepreneurship as both an objective and a subjective activity - which means design thinking is used in 1) value clarification processes - also called transformative design processes, as they lead to changes in identity and behaviour 2) objective processes about the market, potential customers, and finally 3 ) the larger world, which could be a bigger purpose, sustainability, circular economy etc. These different foci are interpretations of Goleman \& Senge's (2014) notion of the Triple Focus, which refers to an 'inner', an 'other' and an 'outer' focus. We will elaborate on design processes aimed at value clarification and an 'inner' focus later in this article.

\subsection{Adding Design Thinking to Entrepreneurship Education}

The DesUni teaching model offers "a significant paradigm shift changing the traditional didactic assumptions of entrepreneurship education. It involves a change in curriculum, teaching methods, use of knowledge, teaching style, teacher-student relations, culture, habitat and 
assessment" [1].

With the DesUni model Nielsen \& Storvang [1] offer a detailed account of the relationship between design thinking and entrepreneurship. With reference to Sarasvathy [29, 30] they argue that entrepreneurship processes are dominated by effectuation logics rather than causation logics. Effectuation is based on the logic of design, whereas causation processes are based on the logics of prediction, rational analysis, planning and control to reach previously defined effects. Traditional entrepreneurship education typically leans towards the causational view [30] with entrepreneurship courses that are organised around a business plan and mainstream management thinking. Both entrepreneurs and designers are creative problem solvers, but they differ especially in terms of focus within the process of opportunity emergence [31]. Design thinking is relevant as it focusses on creating an unknown future [1].

The difference between contemporary entrepreneurship educations based on the rationale of causation and entrepreneurship education based on the idea of design thinking is illustrated in Nielsen \& Storvang's figure below [1].

Design thinking requires a specific mindset, design action and experimentation. Likewise, design thinking cannot develop without imagination and creativity.

\subsection{Design Processes and a Design Mindset}

Sarasvathy [29] explains that all entrepreneurs begin with three categories namely: Who they are, what they know and whom they know. However, Sarasvathy's theory focuses on 'effectuation' as an entrepreneurial way of thinking and not so much on a deeper investigation of the personal passions, values and mental models of the entrepreneur. Nor does she take the significance of empathy, designerly knowledge, or emotional and aesthetic experiences into account unlike
Sørensen \& Evers [11] who explain 'designerly and human-centred entrepreneurship'.

In an interview about entrepreneurship the business professor Steen Hildebrandt argues: “...forget everything about the perfect business model...dares to embark on an inner journey to find meaning" [32]. Similarly, the creativity professor Sir Ken Robinson [4] stresses the importance of finding 'the element'; Stephen Covey uses the term 'voices' [33] and psychology professor Kennon Sheldon uses the phrase 'intrinsic motivation' and 'self-determination theory' [34]. Young students, in particular, need to focus on themselves in order to be aware of their passions, inner strength and limitations [7]. Greene [3] and Langer [16] highlight the human ability to see and change one's own perspective, not only in regard to objective issues, such as new businesses, but also in relation to one's own life - what Blenker et al. call 'an entrepreneurial mindset'.

Yet, this inner perspective has received little attention in the literature about entrepreneurship education (Blenker et al, 2011). However, Blenker et al. [9] identify four different approaches or paradigms to entrepreneurship education: three of these refer to the market and creating change in the world, whereas the last approach refers to the students' way of being, in what they call "an entrepreneurial mindset" (ibid, 2011, 421), also called 'transformative processes' and '(re)constructions of identity'.

In comparison to the DesUni model Nielsen \& Storvang [1] argue that the underlying logic of the DesUni model is inspired by Seelig who "suggests considering both internal and external processes in the student in order to boost transformative changes in students" [1]. The authors claim that the DesUni model includes "a design mindset" and "a pedagogical dimension of the teaching model that assists teachers in bringing out the desired change in the student" (ibid, 982). Yet, the article does not offer a more in-depth explanation of these "transformative changes."

\begin{tabular}{|c|c|c|}
\hline & From conventional education... & To design thinking education \\
\hline $\begin{array}{l}\text { Main question } \\
\text { asked }\end{array}$ & What is? & What might be? \\
\hline Logic & The future is predictable & The future is unknown \\
\hline Problem & Defined up-front, tamed and solved & $\begin{array}{l}\text { Complex, wicked, problem and solution } \\
\text { co-evolute }\end{array}$ \\
\hline Thinking mode & Rational and linier & Human-centred and iterative \\
\hline Constrains & Something to be eliminated & Something positive and exciting \\
\hline Practice & Decoupled from practice & Co-create with practice \\
\hline Tangibility & Low (focus on tacit things) & High (focus on artificial thinks) \\
\hline Pedagogy & Students passive receives of knowledge & Students active creators of knowledge \\
\hline
\end{tabular}

Figure 1. Design thinking and entrepreneurship education (Nielsen \& Storvand, 2015, 980) 
Blenker et al. have identified four paradigms, here described with additional questions related to an educational setting:

1) Training students to create new ventures - How do we train students to start new ventures?

2) Training students to transform ideas and knowledge into economic growth - How do we train students to create high-growth firms?

3) Facilitating entrepreneurial energy for social change - How do we train students to create high-growth firms?

4) Facilitating entrepreneurship as an everyday practice - How do we install an entrepreneurial spirit in students?

Blenker et al. argue that we need an alternative approach that focusses on "building up entrepreneurship as a value-creating meta-competence, 'an entrepreneurial mindset', which can be applied in multiple walks of life and not only in starting a business, becomes a matter of paramount importance" (ibid, 423).

The authors consider entrepreneurship to be an everyday practice "prior to all other forms of entrepreneurial activity" (ibid, 423). Despite the authors' focus on business-oriented values, since they believe that this 'entrepreneurship mindset' will lead to "more enterprising and competitive individuals and organizations," we see many parallels to the more philosophical and human-centred researchers introduced previously: Langer, Greene and Robinson. In particular, we pay attention to Blenker et al.'s definition of the entrepreneurship mindset and the construction and reconstruction of identity and transformation through imagination. This is very much in line with Greene's perception of human beings: "We are always becoming" and her saying: "I am what I am not yet" [36]. Likewise, it points to the human capacity to change one's perspective in relation to one's own life, which is extremely relevant $[2,3,35,4,5$, 8].

Blenker et al. claim that it is very easy to get locked into a particular identity, both professionally and personally, and they present 'imagination' as a core competency in the entrepreneurial mindset. This mindset "...comes into being through interplay between narratives and storytelling." This again influences how the individual constructs or reconstruct his or her identity. As such the authors consider narratives to contribute to the creation of opportunities and identity. "The aim of including storytelling and narratives as part of the entrepreneurship curriculum is to enable students to perceive their own world as one filled with opportunities that originate within themselves and reflect on how this affects their ability to act." Using narratives and storytelling is nothing new, the authors claim (ibid, 434).

\subsection{Design Processes Aimed at the Inner Focus and Self-leadership}

Traditionally, design and design thinking are considered a new approach to problem solving [1], indicating something 'outside' oneself which needs to be solved, changed etc. In more recent design research design processes are also used in relation to subjects, as a meta-cognitive perspective that can help you to 'see' your dominant values and change them [10, 19]. Thus, design thinking and design processes can be used in the creation and recreation or 'reframing' [35, 36, 37, 40] of identity, which is demonstrated in value clarification workshops.

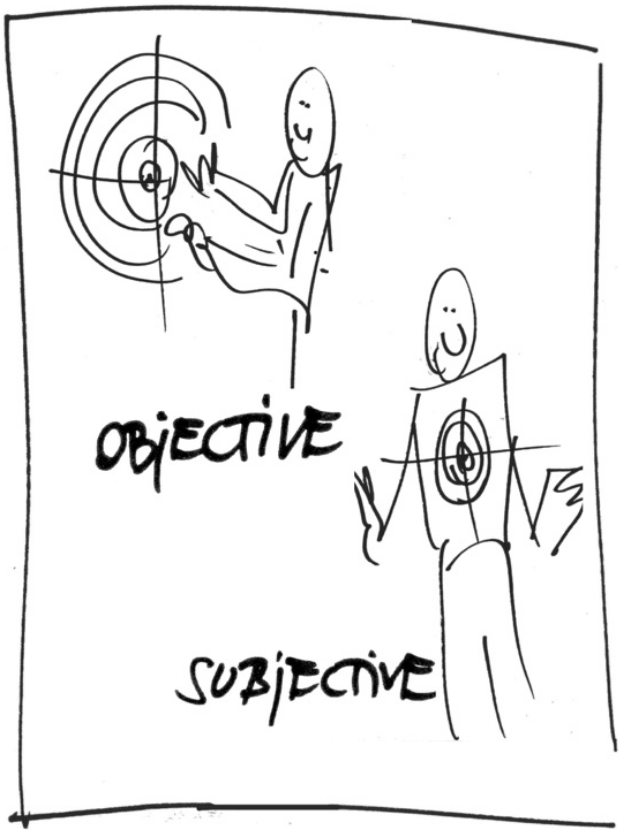

Figure 2. Strategic and transformative design processes focusing on objective or subjective problems or possibilities (illustration is created by the authors)

Value clarification workshops originate in a doctoral design research project [10]. Customers and potential customers in a bank were invited to reflect on and possibly change their money behaviour. The majority changed their money behaviour in accordance with their 'real' personal values. An example was a young student who stated she had changed her money behaviour and her understanding of herself: "I realized that I could not be a 'big spender' being a student" which demonstrates a change in her self-perception and identity. In the doctoral research these design processes were explained in the perspective of self-leadership [41, 42, and Thought-Self-Leadership [43, 10,44]. The key concept is that men and women can exert influence on themselves to control their own thinking and actions. These design processes can also be seen in the perspective of transformative learning processes $[45,46,11]$.

The method has also been tested among entrepreneurs. The value workshops can be seen as 'an inner journey'. They are offered as part of a Danish entrepreneurial initiative (Iværk at Spinderihallerne, Vejle) for creative entrepreneurs in order to stimulate reflection on their own skills and human resources and to reveal dreams and passions. Likewise, they reveal barriers and inappropriate dominant mental models, 
such as 'I hate selling', which is an unpopular activity among creative entrepreneurs.

The creative process integrated in these creative value clarification workshops includes working with materials, as this is a special designerly way of 'thinking with your hands'. In the field of design, generative tools are used as thinking tools or 'making tools', and they have a strong appeal to our visual ways of sensing and expressing ourselves. Generative design processes appeal to our tacit and unconscious knowledge, our feelings and dreams [47, 48]. Here they are used as "a language for self-dialogue aimed at the creativity of the individual" $[10,19]$.

An example from the workshops with entrepreneurs: When participants become aware of their current dominant values they also 'see' their dominant values in what they model. At that moment they need to choose: They can continue living as they used to, now being (more) aware of their dominant values, or they can interpret their values, perhaps even identify new values, to work on 'implementing' them in their thinking and behaviour. Thus, by 'seeing' their dominant values, they are urged to reframe their perception of themselves by doing design - like an artist who used to see herself as 'a passive artist'. She did not 'need to sell her art' because her dominant value from the art scene was: 'art should sell itself'. She changed or reframed her understanding of herself into 'a proactive entrepreneur', showing leadership and developing new types of proactive selling activities as part of her business strategy.

Drawing on Revans [49] and Zuber-Skerrit [50] this particular kind of action research - or action learning or transformative learning $[45,46]$ - aims at technical and practical improvements for the participants' transformed consciousness about themselves and their business. This motivates and empowers them to change themselves and/or their firm's existing boundaries, conditions and, in particular, their ability to see and create possibilities and how to make choices.

\section{Research Methodology}

Based on our research into ways to integrate a more designerly and entrepreneurial approach in elementary education for both teachers and pupils, we have developed and conducted this research:

A qualitative research approach was used in the study, which was conducted at a public school in the city of Odense, Denmark. Methodologically we combined design thinking [37, 51, 52 38] and design processes aimed at value clarification [10] with Design-based Research [53]. The aim of Design-based Research is to create a research design which can investigate theoretical hypotheses and while also develop prototypes that can be used in the educational system.

\subsection{Main Research Questions}

In entrepreneurship education we tend to focus on single subjects such as the students, the students' motivation, self-directed learning etc. We argue that we need to look critically at the bigger picture, asking the research question: How can we understand the challenge that entrepreneurial learning poses to the teacher's role and the learning culture in schools? And additionally, how can we develop entrepreneurship education that meets these challenges?

\subsection{Theoretical Research Hypotheses}

Our theoretical research hypotheses were:

a) We will support the pupils' motivation for learning and influence them and their learning by making their values and choices more visible through design thinking and design activities.

b) We will support teachers in seeing and presenting subject matters as numerous opportunities for learning through design thinking and visualisation.

To investigate our hypotheses we:

a) offered the students different design processes, including generative tools, as a more direct access to - and an understanding of - their own values $[10,44$, 54].

b) redesigned or reframed [38] subject matters into different types of learning roles that presented new possibilities from which the pupils and the teachers could learn and choose.

Design processes represent a distinct mode of knowing and reflecting $[52,55,38]$. 'Designerly ways of knowing' [51] or 'designerly' represent methodologies or issues specific to design. A design process represents a higher order skill [38] and another way of reflecting ('reflection-in-action') [39]- a reflection that includes 'thinking with the hands' [56, 61].

Design processes often incorporate 'various types of props and materials in order to stimulate this type of reflection. Some of them are referred to as generative tools, also known as 'thinking tools'. The basic assumption of the study is that offering students design thinking as a kind of visual-making language presents the opportunity for reflection on values and also on the subject matters for interpretation. It is not easy, particularly for elementary school students, to identify what matters to them, or find new ways of learning on their own. Therefore, our hypothesis is that these design thinking processes, visual making and doing processes can support self-directedness and self-leadership [19] also in students' learning situations. 

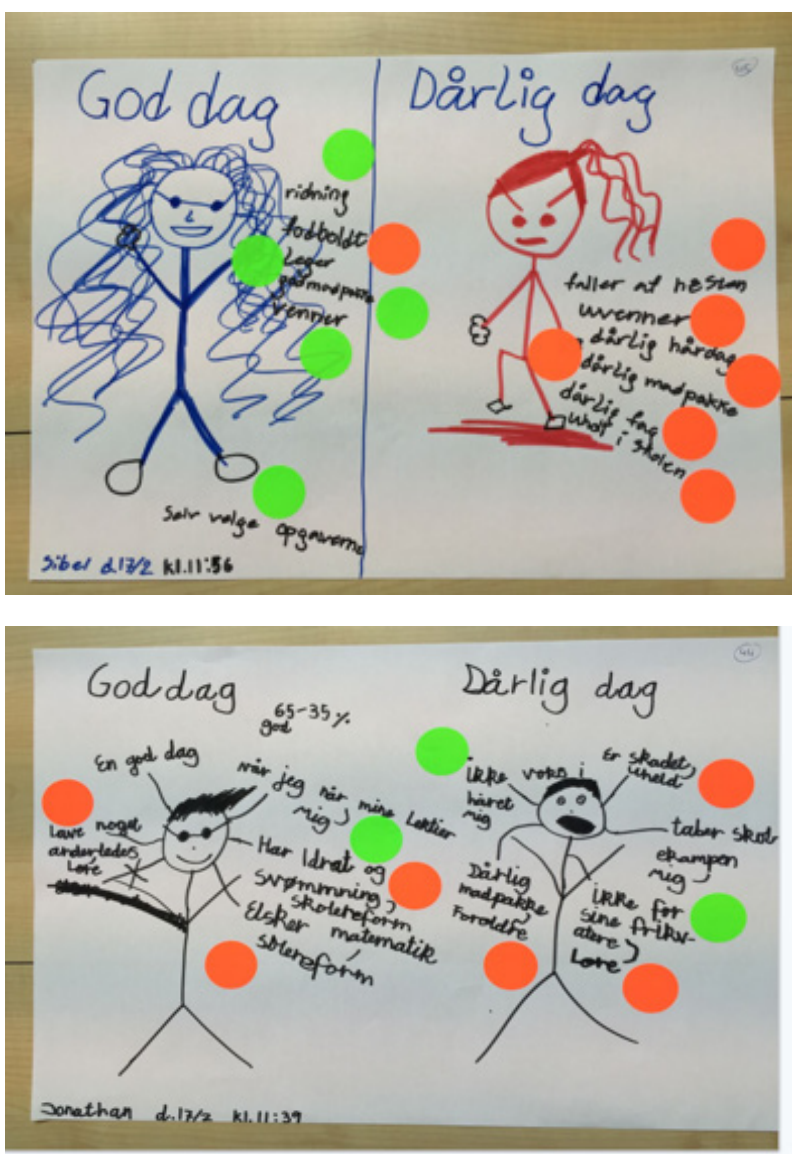

Figure 3. Two examples of students 'collages illustrating both 'a good day at school' (left) and 'a less good day at school' (right side of page)

\subsection{Research Design}

In our workshops the students were given various generative design exercises that made them reflect on learning, school, being a pupil etc. One of the exercises was to illustrate themselves on 'a good day at school' and write five things or situations that contributed to 'a good day', such as 'a good packed lunch' or 'a fun game in the schoolyard'. The next exercise was to indicate the person(s) who was/were the reason for, or involved in, the situation, e.g. 'my mother made my packed lunch', or 'my classmates were part of the fun game in the schoolyard' etc. Finally, we asked whether or not the students found that they had an influence on these different situations. 'No influence or little influence' involved adding a red dot, and 'influence or some influence' involved adding a green dot.

In this workshop the students were also presented with our learning programme that included four different learning roles offering very different assignments to choose from. The different learning roles supported teachers and students in interpreting the same learning objective in different ways. Seeing subject matters from various perspectives is a central element in design thinking $[39,38]$. Our study offered four well-known ways of getting to know the world as learning roles: investigating the world, sensing the world, exploring the world and speaking with others.

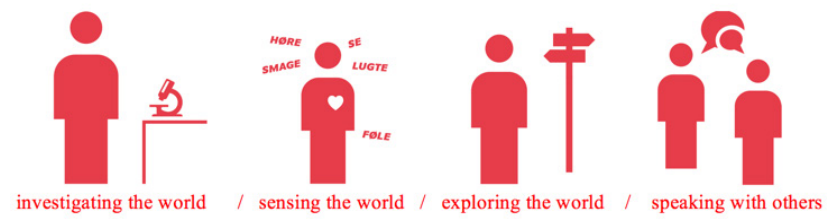

Figure 4. Illustration of the four different learning roles

These roles were a key element in a learning programme about the Swedish children's author, Astrid Lindgren. The central learning objective of the programme was the 'interpretation of literary texts', and this objective was divided into more specific learning goals such as 'analysing the persons in the novel'. Thus, the students were offered four different tasks that related to each learning goal, and they would all become familiar with that same learning goal, but in different ways.

In this learning programme the students were gaining the freedom to choose how to learn, the opportunity to reflect on their preferences for a learning role, and also the reason why they preferred or felt a stronger motivation for choosing one learning role over another. Moreover, the students were welcome to develop their own assignment, which provides the ultimate opportunity and goal: that the students make the material meaningful to themselves [16].

After the six weeks learning programme the creative workshop was repeated including the same assignments.

\section{Results}

Information gathered from two classes included data from the 'before' and 'after' workshop, observations from the six weeks programme and interviews with teachers. The data indicated a clear pattern that the pupils were very happy to have the opportunity to choose, and they were generally able to engage in a more active way of learning. However, reflecting on their own values and learning preferences seemed to be difficult for them. Our conclusions were:

\subsection{Theoretical Research Hypotheses}

Our theoretical research hypotheses were:

a) students feel they have influence on various issues in their lives and at school, yet not on the teaching

b) it is difficult for students to reflect on learning and therefore difficult to see their own values and motivation for learning

c) having choices seemed to stimulate the students' motivation for learning significantly

d) teachers have difficulties leaving the traditional leading teacher role and did not engage in the learning processes

e) teachers have difficulties reframing the learning goals 
Few of the students demonstrated a high degree of reflection and responsibility, independence and persistence, and a majority demonstrated only a relatively high degree of reflection about their learning, which we consider to be the first step to self-directed learning prior to taking leadership and responsibility. According to Knowles, self-directed learning '...describes a process by which individuals take the initiative, without the assistance of others, in diagnosing their learning needs, formulating learning goals, identify human and material resources for learning, choosing and implementing appropriate learning strategies, and evaluating learning outcomes"[57].

The critical dimension in self-directed learning is the learner's active control of the learning process.

Our research study in a public school revealed that pupils are far from self-directed; rather they feel detached from learning and schools. Seen from the pupils' perspective teachers and principals are controlling their learning. We consider this to be the reason why students do not connect personal values to learning. As soon as the pupils have choices and opportunities to select from they do become actively engaged in the learning processes.

Our interviews with teachers revealed in particular two interesting issues: We see two basic, but paramount problems:

- Teachers are very much in control and are guiding the students. The goal for the specific lesson leaves no room for flexibility (due to new demands about learning goals). According to the teachers their overall motivation and purpose have shifted from "when I can see the students' growth" to "the grades, they are our bottom line," which represents a purpose of "meeting the overall demands for me as an employee."

- We laid out a proposal for a new way of teaching: the teachers would be asked to take the students' interest into account and understand their resources and preferences. They would need to take on a new role without controlling the students' learning and the outcome of the lesson. This presented a real challenge to them.

Our overall conclusion is therefore that we tend to focus on the students, the students' motivation and self-directed learning in entrepreneurship education as well, but we also need to look critically at the bigger picture. This paradigmatic conflict results in various specific and challenging issues, like the teacher's role and the learning culture that again influences the students' motivation and their opportunity and ability for self-directed learning.

\subsection{A Lack of Essential Human Freedom}

In our research we found that this paradigmatic conflict results in a lack of an essential human freedom to create new interpretations that guide learning for the individual, which, of course, impacts or even ruins the ability to become entrepreneurial and have an entrepreneurial mindset [9]. In traditional learning the teachers are setting the goals and the students are asked to reproduce what is already well-known. Public schools are, as Robinson [4, 5], Claxton [6], Hildebrandt [58] and Goleman \& Senge [8] argue, designed for the Industrial Age. Similarly, the educational philosopher Maxine Greene agrees that in traditional education the subject matter is seen as a one-dimensional, obvious reality in the same manner as we are seeing our everyday reality "...as a given, objectively defined reality, impervious to change," as Greene states [2]. People do not seem to realise that they have choices, nor are they aware of what they really want and what they are capable of achieving. Hence Greene introduces the term "wide-awakeness" as a goal for education. She argues: "When I think of what my students really need, it has nothing to do with test scores. It has to do with a way of thinking - reflecting on self and the world in which they live in order to make change. 'Wide-awakeness' is a philosophical approach to life and about feeding and using our imagination and about creating the possibility for "a new dimension of a self-in-the-making" [59].

Therefore, in order to become more mindful as human beings we need an increased awareness in education regarding: creativity, imagination and the ability to see and create alternatives and new potentials, including the ability to change things in our personal life and in our surroundings and even the ability to change our identity.

From this perspective, a design-oriented entrepreneurship education represents - or has the option of representing - a new perspective. Entrepreneurship is capable of presenting a new way of perceiving learning in educational institutions. It is, however, a challenge in most educational institutions. Integrating small changes, like the demonstrated assignments put forward in this research, might have a substantial impact.

\section{Conclusions and Further Perspectives}

"Children go into schools as question marks and come out as periods" (Neil Postman). Today children are self-directed learners until they start school. During their school years they become more and more other-directed. Before children start school they learn through playing, exploring the world and by being curious. In that sense learning was not an activity that occurred outside their daily lives. Learning was continual and in synch with life. When children start school life stops as they learn, as learning is not in synch with life [15].

Our educational institutions were designed in the industrial age. They have only undergone incremental changes, not radical changes in a way that better corresponds to society and the human needs of today. Therefore, we are talking about a paradigmatic conflict in entrepreneurship education.

We see two basic, but paramount problems:

- In our way of solving problems we tend to look at details rather than looking at and understanding the 
bigger picture. This is what Peter Senge called 'detail complexity' versus 'dynamic complexity' [60]. Thus, we focus on e.g. 'students' motivation', 'learning goals' or 'courses 'about' entrepreneurship' etc.

- We are challenged by our dominant values and mental models to an extent that we barely notice when we are thinking and acting within our Industrial Society logic. This presents a challenge for all of us: teachers, students, school principals, parents, researchers etc.

$[7,15,16,17,2,3]$ in our everyday activities as well as in our suggestions for innovations.

We believe our suggestion points in the right direction. In this article we have demonstrated some concrete possibilities and examples of how to use a designerly approach and design thinking in public schools, a suggestion that confronts actual problems and is related to this overall paradigmatic conflict in entrepreneurship education. The design perspective adds a new creative approach that includes working with imagination; it adds new methods and combines thinking and doing. In that sense it offers "a significant shift in paradigm changing the traditional didactic assumptions of entrepreneurship education" [1]. Additionally, our research adds a design process that offers a possibility for students to reflect on their individual values which stimulates a stronger inner focus and ensures that the students learn important, basic human - and entrepreneurial - skills: reflecting on their own learning, seeing more perspectives and learning to make choices.

\section{REFERENCES}

[1] Nielsen, S. L. \& Storvang, P. (2015) DesUni: university entrepreneurship education through design thinking in Education + Training. Vol. 57 Iss 8/9 pp. 977-991

[2] Greene, M. (1978). Landscapes of Learning. Teachers College Press

[3] Greene, M. (1995). Releasing the Imagination. Essays on Education, the Arts, and Social Change. John Wiley \& Sons, Inc.

[4] Robinson, K. (2010). The Element: How Finding Your Passion Changes Everything. Penguin.

[5] Robinson, K. (2011). Out of Our Minds - Learning to be Creative. Capstone; 2nd edition 2011

[6] Claxton, G. (2008) What's the Point of School? Discovering the Heart of Education. Oneworld Publication.

[7] Goleman D. \& Senge, P. (2014) The Triple Focus: A New Approach to Education. More Than Sound

[8] Goleman D. \& Senge, P. (2014) in Reflections the SoLJournal on Knowledge, Learning, andChange.Vol. 4 no. 1.

[9] Blenker, P. Korsgaard, S., Neergaard, H. \& Thrane, C. (2011)
The Questions we care about: paradigms and progression in entrepreneurship education. In Industry \& Higher Education. Vol. 25, No. 6.

[10] Sørensen, K. B. (2011): When Designing Emerges into Strategies - in an organisation and in individuals. Ph.D. Thesis. Kolding School of Design, Denmark, 2011.

[11] Sørensen K.B. \& Evers, W. (2015) The role of doing and making models with materials: Outlining "designerly \& human-centered entrepreneurship" Eksig 2015 Conference (part of Design Research Society)" Tangible Means: Experiential Knowledge Through Materials" Kolding. Nov. $25 \& 262015$

[12] Robinson, S. \& Blenker, P. (2013) Tensions between rhetoric and practice in entrepreneurship education; an ethnography from Danish higher education. European Journal of Higher Education. Published online: 30 Oct 2013: 1-16

[13] Pittaway, L. \& Edwards, C. (2012) Assessment: examining practice in entrepreneurship education in Education + Training. Vol. 54 Nos 8/9 pp. 778-800.

[14] Ronstadt, R. (1990) Contributing editor's feature in Entrepreneurship Theory and Practice. Vol. 15. No.2, 79-92.

[15] Siemens, G. (2006) Knowing Knowledge. www.knowingknowledge.com

[16] Langer, E. J. (1997) The Power of Mindful Learning Da Capo Press

[17] Langer, E. J. (1989, 2004) Mindfulness. Da Capo Press

[18] Hornstrup, C. \& Johansen, T. (2013) Strategisk relational ledelse - Systemisk ledelse af forandringer. Viborg, DK: Dansk Psykologisk Forlag.

[19] Sørensen, K.B. (2013). Designing for self-leadership in Proceedings of NORDES 2013: Experiments in design research. Copenhagen: The Royal Danish Academy of Fine Arts, Schools of Architecture, Design and Conservation, s. $163-17310 \mathrm{~s}$

[20] Boland. R. \& Collopy, F. (2004) Managing as Designing. Stanford Business Books; 1 edition (July 28, 2004

[21] Martin, R. (2009) Design of Business: Why Design Thinking is the Next Competitive Advantage. Harvard Business Review Press

[22] Osterwalder A \& Pigneur, Y (2010). Business model generation: A handbook for visionaries, game changers, and challengers. Amsterdam: Modderman Drukwerk 2009.

[23] Stickdorn, M. \& Schneider, J.: This is Service Design Thinking: Basics, Tools, Cases. Wiley; 1 edition (January 11, 2012)

[24] Sangiorgi, D. (2011) Transformative Services and Transformation Design in International Journal of Design, Vol. 5, No. 2. (2011)

[25] Michlewski, K. (2008) Uncovering Design Attitude, Inside the Culture of Designers in Organizational Studies, Vol. 29, No. 3, pp. $373-392$

[26] Michlewski, K. (2015) Design Attitude. Routledge; New edition edition (March 19, 2015)

[27] Dunne, D. \& Martin, R. (2006) Design thinking and how it will 
change management education: an interview and discussion Academy of Mangement Learning and Education, Vol. 5, No. $4,512-523$

[28] Neck, H.M. \& Greene, P.G. (2011) Entrepreneurship education: known worlds and new frontiers Journal of Small Business Management Vol. 49, No. 1 55-70.

[29] Sarasvathy S, (2001) What makes entrepreneurs entrepreneurial? Washington, DC: University of Washington School of Business.

[30] Sarasvathy S, (2008) Effectuation: Elements of Entreprenerial Expertise, Edward Publising, Cheltenham

[31] Nielsen, S.L. \& Christensen, P. R.(2014) The Wicked Problem of design management: perspectives from the field of entrepreneurship The Design Journal Vol. 17, No. 4, 560-582.

[32] Matzen, P. (2013) Theory U, Stop downloading and start listening. Interview with Steen Hildebrandt in Aarhus Affairs, \#2, 2013

[33] Covey, S. R. (2005) The 8th Habit - From Effectiveness to Greatness. Free Press

[34] Sheldon, K. (2012) Motivation - viden og varktøj fra positiv psykologi. Mindspace, 2012 (Translated from the English version: Positive Motivation - A six week course. (2008)

[35] Langer, E. J. (1989, 2004) Mindfulness. Da Capo Press

[36] Pinar, W. F. (1998) The Passionate Mind of Maxine Greene 'I am ... not yet'. (Falmer Press, 1998)

[37] Lawson, B. (1980) How Designers Think: The Design Process Demystified. London: Architectural, 1980

[38] Lawson, B. \& Dorst, K. (2009) Design Expertise. Taylor \& Francis (2009)

[39] Schön, D. 1983. The Reflective Practitioner. New York: Basic Books

[40] Paton, B. \& Dorst, K. (2010) Briefing \& Reframing in Proceedings of DTRS8: Interpreting Design Thinking University of Technology, Sydney - Faculty of Design, Architecture and Building Oct. 19-20. 2010.

[41] Neck, C. P., Neck, H.M., Manz, C.C., Godwin, J. (1999). I think I Can, I think I Can - A Self-Leadership Perspective toward Enhancing Entrepreneur Thought Patterns, Self-Efficacy and Performance, in Journal of Managerial Psychology 14, No 6, 477-501.

[42] Neck, C.P. \& Houghton, J.D. (2006) Two decades of selfleadership theory and research: Past developments, present trends, and future possibilities in Journal of Managerial Psychology, Vol. 21 Iss: 4, pp.270 - 295

[43] Neck, C. P. \& Manz, C.C. (1992). Thought Self-Leadership: The Influence of Self- Talk and Mental Imagery on Performance. Journal of Organizational Behavior Vol. 13, No. 7, 681-699.

[44] Sørensen, K. B. (2012) Designing as a language for self-dialogue and value clarification in Proceedings of Design
Research Society Conference Bangkok July 2012: Reforming traditions, reshaping boundaries.

[45] Mezirow, J. (1991). Transformative Dimensions of Adult Learning. San Fransisco: Jossey-Bass Publishers.

[46] Illeris, K. (2013). Transformativ laering og identitet. Samfundslitteratur.

[47] Visser, F. S., Stappers, J. P. \& Lugt, V. R. (2005): Contextmapping: experiences from practice. To appear in CoDesign: International Journal of CoCreation in Design and the Arts, Vol. 1 No. 2, Taylor and Francis, 2005

[48] Brown, S. (2014) The Doodle Revolution. Unlock the power to think differently. Penguin Group

[49] Revans, R. (1982) The Origins and Growth of Action Learning. Chartwell-Bratt, Bromley.

[50] Zuber-Skerrit, O (2001) Action Learning and Action Research in: Sankara, S., Dick, B. and Passfield, R. (eds) Effective Change Management through Action Research and Action Learning. Lismore, Australia, pp. 1-20.

[51] Cross, N. (1982) Designerly Ways of Knowing in Design Studies, vol 3 no 4 October 1982 pp. 221-227

[52] Cross, N. 2006. Designerly Ways of Knowing. Berlin: Springer

[53] Amiel, T. \& Reeves, T. C. (2008) Design-Based Research and Educational Technology: Rethinking Technology and the Research Agenda. Educational Technology \& Society, 11 (4), $29-40$.

[54] Sørensen, K. B. (2012) Designing as a language for self-dialogue and value clarification in Proceedings of Design Research Society Conference Bangkok July 2012: Reforming traditions, reshaping boundaries.. 2012.

[55] Cross, N. 2004. "Expertise in Design: An Overview." Design Studies, 25(5): 427-41.

[56] Pallasmaa, J. (2009) The Thinking Hand. Existential and Embodied Wisdom in Architecture. Wiley.

[57] Knowles, M. S. (1989). The making of an adult educator: An autobiographical journey. San Francisco: Jossey-Bass

[58] Hillebrandt, S. (2012) Børnene er det vigtigste, fremtiden, skolen og barnet. Turbine.

[59] Greene, M. (2007) Countering Indifference - The Role of the Arts by Maxine Greene. www.maxinegreene.org. retrieved 25.03.16

[60] Senge, P. (2006) The Fifth Discipline: The art and practice of the learning organization: Second edition

[61] Bamberger, J. \& Schön, D. A. (1983) Learning as Reflective Conversation with Materials: Notes from Work in Progress. Art Education. Vol. 36, No. 2, Art and the Mind, pp. 68-873 Published by: National Art Education Association.

[62] Dweck, C. S. (2008) Mindset The New Psychology of Succes. How we can learn to fulfill our potential. Ballantine Books 